\title{
Effect of Foliar Feeding of Nutrients and Gibberellic Acid on Yield and Quality of Mango (Mangifera indica L.) Fruits cv. Dashehari
}

\begin{abstract}
Background: Mango is national fruit of India and it is suffering with many problems in cultivation among which fruit drop is major which leads to low production. So, the application of nutrients and plant growth regulators would be helpful to minimize fruit drop and to get better yield with quality fruits. The aim of the present study to study the effect of foliar feeding of nutrients and gibberellic acid on yield and quality of mango (Mangifera indica L.) fruits cv. Dashehari.

Methods: This study was conducted at Horticulture Farm, Rajawala and in PG Laboratory of Doon (PG) College of Agriculture Science and Technology, Camp Road, Selaqui, Dehradun during the years 2017-2018 with the use of $\mathrm{GA}_{3}(100 \mathrm{ppm}), \mathrm{Urea}(1.5 \%)$ and Boron $(0.2 \%)$ alone and in combinations, these all were compared with control treatment.

Result: All the treatments used were found better to improve the yield and quality of fruit but the treatment combination of Boron $(0.2 \%)+$ Urea $(1.5 \%)+\mathrm{GA}_{3}(100 \mathrm{ppm})$ was found significantly effective to increase the fruit retention, fruit yield, fruit length, fruit width, fruit weight, total soluble solids, ascorbic acid and sugars. However, fruit drop and titrable acidity were drastically decreased while the fruit volume was found non-significant.
\end{abstract}

Key words: Cultivars, Fruit quality, Gibberellic acid, Nutrients, Yield.

\section{INTRODUCTION}

Mango (Mangifera indica L.) is a member of the Anacardiaceae family and one of the most commercially grown in India. It is considered as the king of fruits in many countries (Purseglove, 1972). In India mango is extensively grown in U.P. Bihar, Karnataka, Tamil Nadu and Andhra Pradesh. Other states where mango is an important crop are Madhya Pradesh, West Bengal and Maharashtra. In India, an area under mango cultivation was 2,212 million hectares with an annual production of 195.06 lakh tones while in Uttarakhand state, the area under mango cultivation was about 130.01 thousand hectares with a production of about 911.3 thousand MT (Anonymous, 2017) during the 2017. Mango is a good source of different nutrients fat, protein, carbohydrate, vit-C and highest vit-A content at ripe stage among all fruit crops. Fruit pulp predominates in water, carbohydrates, organic acids, fats, minerals, pigments, tannin and vitamins. Dashehari mangoes are long and ovalshaped with light green or yellow-green skin when mature becoming golden yellow when ripe. Dashehari mangoes have fibreless peach coloured flesh with medium-sized stone, the flavour is very sweet and aromatic. The fruit drop is heavy during first three weeks of fruit set when the rate of fruit development is rapid and it continues up to the fifth week (Ram, 1983).

Among different fertilizers, urea is important because it supplies nitrogen which is essential nutrients for plant growth and development. For these several investigations showed that plant growth regulating substances plays an important role in terms of both quality and quantity improvement of
'Department of Fruit Science, Rani Lakshmi Bai Central Agricultural University, Jhansi-284 003, Uttar Pradesh, India.

${ }^{2}$ Department of Horticulture, Doon (PG) College of Agriculture Science and Technology, Dehradun-248 011, Uttrakhand, India.

${ }^{3}$ Department of Vegetable Science, Banda University of Agriculture and Technology, Banda-210 001, Uttar Pradesh, India.

Corresponding Author: G. Vishwakarma, Department of Fruit Science, Rani Lakshmi Bai Central Agricultural University, Jhansi284 003, Uttar Pradesh, India. Email: govind0139@gmail.com

How to cite this article: Rabbani, S., Vishwakarma, G., Soni, S. and Zaman, F. (2022). Effect of Foliar Feeding of Nutrients and Gibberellic Acid on Yield and Quality of Mango (Mangifera indica L.) Fruits cv. Dashehari. Indian Journal of Agricultural Research. DOI: 10.18805/IJARe.LR-4742.

Submitted: 20-07-2021 Accepted: 08-11-2021 Online: 04-03-2022

carbohydrates reserve for good vegetative growth and flowering in mango. In view of different works on many fruit crops shown that plant growth regulations have capacity to enhance productivity of fruits by bringing out a change in nutritional and hormonal status of the plant (Tripathi and Shukla 2006). Other than plant nutrients, plant growth regulators like gibberellic acid generally regulate the fruit ripening process and maintain the fruit health during storage (Martinez-Romero et al., 2000). Some researchers found that plant growth regulators play an important role in terms of improvement of quality and quantity in mango. A fertilizer like urea is an important essential nutrient of nitrogen which requires for plant growth and development. Sufficient 
carbohydrates reserve is essential for good vegetative growth and flowering in mango and $\mathrm{GA}_{3}$ regulators generally regulate the fruit growth process and maintain the fruit growth and development.

\section{MATERIALS AND METHODS}

The present investigation entitled "Effect of foliar feeding of nutrients and gibberellic acid on fruit yield and fruit quality of mango cv. Dashehari was conducted at Horticulture Farm, Rajawala and in PG Laboratory of Doon (PG) College of Agriculture Science and Technology, Camp Road, Selaqui, Dehradun during the years $2016-2017$ at $30.3165^{\circ} \mathrm{N}$, $78.0322^{\circ} \mathrm{E}$ and $447 \mathrm{MSL}$. The temperature during hot weather commences by about end of February and ends by about the middle of June. Monsoon is warm and moderately humid. It commences in the middle of June and ends in the middle of September. The soil of Dehradun medium and the plant growth is bound to affect profoundly the rate of growth of plants and ultimately the final yield through its properties. Therefore, an attempt was made to assess the physical and chemical properties of soil of the experimental field. To evaluate the initial soil fertility status of soil, samples were collected from the experimental field before sowing of crop taken randomly from different parts up to a depth of 0 $30 \mathrm{~cm}$ and a composite sample was prepared which was subjected to mechanical and chemical analysis as per the procedure. The experiment was carried out on ten years old trees of Dashehari cultivar of mango. They are suitable for high density planting.

The experiment consists an eight treatments combinations as $\mathrm{T}_{1}-\mathrm{GA}_{3}(100 \mathrm{ppm}), \mathrm{T}_{2}$-Urea $(1.5 \%), \mathrm{T}_{3}-$ Boron (0.2\%), $\mathrm{T}_{4}$ - Boron (0.2\%) + $\mathrm{GA}_{3}(100 \mathrm{ppm}), \mathrm{T}_{5}$ - Urea $(1.5 \%)+\mathrm{GA}_{3}(100 \mathrm{ppm}), \mathrm{T}_{6}-$ Boron $(0.2 \%)+$ Urea $(1.5 \%)$, $\mathrm{T}_{7}$ - Boron $(0.2 \%)+$ Urea $(1.5 \%)+\mathrm{GA}_{3}(100 \mathrm{ppm})$ and $\mathrm{T}_{8}-$ control and replicated thrice. Means were compared with randomized block design, described by Ranganna (1979). The experiment was conducted to access the Impact of Urea, Boron and $\mathrm{GA}_{3}$ on yield and quality parameters of mango viz. fruit retention (\%), fruit drop (\%), fruit yield $(\mathrm{kg} /$ tree), fruit length $(\mathrm{cm})$, fruit width $(\mathrm{cm})$, fruit weight $(\mathrm{g})$, specific gravity, fruit volume (cc), total soluble solids ( ${ }^{\circ}$ brix), titrable acidity, ascorbic acid (mg/100 g pulp), reducing sugar (\%), non-reducing sugar (\%) and total sugar (\%). Well decomposed FYM @ 100 kg per tree and chemical fertilizers $750 \mathrm{~g} \mathrm{~N}, 160 \mathrm{~g} \mathrm{P}_{2} \mathrm{O}_{5}$ and $750 \mathrm{~g} \mathrm{~K}_{2} \mathrm{O}$ per tree were applied in all the selected trees. In the first dose of nutrients includes $50 \%$ of nitrogen and $100 \%$ of phosphorus and potassium applied during June month of 2016 and remaining $50 \%$ of nitrogen was applied during February 2017 after 8 months of the first dose at fruit setting stage.

\section{RESULTS AND DISCUSSION}

\section{Flowering and fruiting behaviours}

The data obtained regarding fruit drop also shows a better response with the use of nutrients and plant growth regulators in a good combination. The lowest fruit drop $(64.50 \%)$ was noted under the treatment $\mathrm{T}_{7}$ : Boron $(0.2 \%)+$ Urea $(1.5 \%)+\mathrm{GA}_{3}(100 \mathrm{ppm})$ followed by $\mathrm{T}_{5}$. Urea $(1.5 \%)$ $+\mathrm{GA}_{3}(100 \mathrm{ppm})$. Whereas maximum fruit drop per cent $(83.75 \%)$ recorded under the treatment control.

The results noted regarding fruit retention and fruit yield presented in the Table 1.1 shows the significant response with the combined use of nutrients and plant growth regulators. The treatment Boron $(0.2 \%)+$ Urea $(1.5 \%)+$ $\mathrm{GA}_{3}(100 \mathrm{ppm})$ shows highest fruit yield and the treatments $\mathrm{T}_{5}$ : Urea $(1.5 \%)+\mathrm{GA}_{3}(100 \mathrm{ppm})$ and $\mathrm{T}_{6}$ : Boron $(0.2 \%)+$ Urea $(1.5 \%)$ were found at par with the treatment $\mathrm{T}_{7}$ : Boron $(0.2 \%)+$ Urea $(1.5 \%)+\mathrm{GA}_{3}(100 \mathrm{ppm})$ while control showed lowest result for fruit retention and fruit yield.

The results regarding fruits yield, fruit retention and fruit drop were noted significant due to the different micronutrient and gibberellic acid when sprayed alone or in combination involved directly in various physiological processes and enzymatic activity for the higher accumulation of food materials and thus, ultimately increased yield. Boron involves in translocation of starch to fruit resulted in better photosynthesis and accumulation of starch in fruits. The balance of gibberellins in the plant also regulates the fruits drop or retention in plants, which ultimately increased the total number of fruits per tree. The role of boron is also reported in fruit set, which ultimately increases the yield. The above results were confirmed by the findings of Hamdy et al. (2007), Singh et al. (2009), Nehete et al. (2011) and Bhowmick et al. (2012) in mango, Babu et al. (2007) in mandarin, Hasani et al. (2012) in pomegranate and Jat and Kacha (2014) in guava.

\section{Physical characters of fruit}

It seems from the data presented in the Table 1.1 that foliar sprays of nutrient and plant growth regulators give significant result regarding fruit size. The maximum fruit length (11.75 $\mathrm{cm}$ ) was noted with the foliar application of $\mathrm{T}_{7}$ : Boron $(0.2 \%)$ + Urea $(1.5 \%)+\mathrm{GA}_{3}(100 \mathrm{ppm})$ which were found at par with the treatment $\mathrm{T}_{5:}$ Urea $(1.5 \%)+\mathrm{GA}_{3}(100 \mathrm{ppm})$ followed by $\mathrm{T}_{6}$ : Boron $(0.2 \%)+$ Urea $(1.5 \%)$ and maximum fruit width $(7.81 \mathrm{~cm})$ also noted with the $\mathrm{T}_{7}$ : Boron $(0.2 \%)+$ Urea $(1.5 \%)$ $+\mathrm{GA}_{3}(100 \mathrm{ppm})$ followed by $\mathrm{T}_{5:}$ Urea $(1.5 \%)+\mathrm{GA}_{3}(100 \mathrm{ppm})$. The control treatment without any nutrient or plant growth regulator spray reported the lowest results regarding both fruit length and width in comparison to all other treatments.

The increase in length, width and weight of mango fruit by foliar spray of urea and boron might be due to reflection of increased vegetative growth as well as increased chlorophyll content of leaves which might have resulted in the synthesis of more metabolites and accumulation of sink, that ultimately resulted in the increment of physical traits of fruit viz. fruit length, width and weight. Results are results are in conformity with Vejendla et al. (2008) noted higher pulp $(71.90 \%)$ in mango cv. Amrapali with the spraying of $\mathrm{ZnSO}_{4} @ 0.75 \%$ and also Moazzam et al. (2011) noted maximum pulp weight and less stone weight in comparison 
to control with foliar application of $0.4 \% \mathrm{FeSO}_{4}+0.8 \% \mathrm{H}_{3} \mathrm{BO}_{3}$ $+0.8 \% \mathrm{ZnSO}_{4}$ and some others like Kumar et al. (2014) in phalsa, Vishwakarma et al. (2013) in aonla, Pandey et al. (2014) in mango.

\section{Chemical characters of fruit}

It seems from the data presented in the Table 1.2 that the combine application of micro-nutrients and plant growth regulators gave the significant response to increasing the total soluble solids (TSS) content in the fruit of mango. Among the different treatment combinations maximum) TSS $\left(21.88{ }^{\circ}\right.$ Brix) was observed under the treatments $\mathrm{T}_{7}$ : Boron $(0.2 \%)+$ Urea $(1.5 \%)+\mathrm{GA}_{3}(100 \mathrm{ppm})$ followed by the treatment $\mathrm{T}_{5}$ : Urea $(1.5 \%)+\mathrm{GA}_{3}(100 \mathrm{ppm})$. The other treatment combinations were also giving a better response among which the control, which does not have any nutrient or growth regulators, gave lowest (17.95 ${ }^{\circ}$ Brix) result over all other treatments.

The sugars viz. reducing sugar, non-reducing sugars and total sugars were also analysed and found great increment in the fruit. The treatment combination $\mathrm{T}_{7}$ : Boron $(0.2 \%)+$ Urea $(1.5 \%)+\mathrm{GA}_{3}(100 \mathrm{ppm})$ gave the maximum reducing sugar $(4.12 \%)$, non-reducing sugars $(13.65 \%)$ and total sugars $(17.77 \%)$ while other treatments were also given a significant increase in sugars but the treatment $\mathrm{T}_{8}$ : control was noted lowest.
The ascorbic acid content of fruit was determined according to the method decided in A.O.A.C. (1975). It was evident from data that the ascorbic acid content in pulp was considerably influenced by the foliar application of a different combination of nutrients and plant growth regulators. The highest ascorbic acid (43.34 mg / $100 \mathrm{~g}$ pulp) content was obtained with the foliar spray of Boron $(0.2 \%)+$ Urea $(1.5 \%)$ $+\mathrm{GA}_{3}(100 \mathrm{ppm})$ followed by $\mathrm{T}_{5}$ : Urea $(1.5 \%)+\mathrm{GA}_{3}(100$ ppm) and the lowest (39.55 mg / $100 \mathrm{~g}$ pulp) ascorbic acid content was obtained under control.

As an increase in acidity content in the fruit is not beneficial to the consumer so the fruit having the lowest acidity content is better. With the combine application of nutrients and plant growth regulators minimize the acidity content in the mango fruit. The treatment $\mathrm{T}_{-7}$ - Boron $(0.2 \%)$ + Urea $(1.5 \%)+\mathrm{GA}_{3}(100 \mathrm{ppm})$ was found better among all other treatments which have minimum acidity percentage $(0.134 \%)$ followed by $T_{5:}$ Urea $(1.5 \%)+\mathrm{GA}_{3}(100 \mathrm{ppm})$. Even though rest other treatments were also found better to decrease the acidity percentage in the fruit among all the treatments.

Acidity content of fruit decrease with the foliar application of nutrients might be due to increase in translocation of carbohydrates and increase metabolic conversion from acidity to sugar by the reaction involving reversal of glycolytic pathway by used in respiration or both

Table 1.1: Effect of foliar feeding of nutrients and gibberellic acid on fruit on yield and yield attributing characters of mango.

\begin{tabular}{|c|c|c|c|c|c|c|c|}
\hline Treatments & $\begin{array}{c}\text { Fruit } \\
\text { retention } \\
(\%)\end{array}$ & $\begin{array}{r}\text { Fruit } \\
\text { drop } \\
(\%)\end{array}$ & $\begin{array}{c}\text { Fruit } \\
\text { yield } \\
\left(\mathrm{kg} \mathrm{tree}^{-1}\right)\end{array}$ & $\begin{array}{c}\text { Fruit } \\
\text { length } \\
(\mathrm{cm})\end{array}$ & $\begin{array}{r}\text { Fruit } \\
\text { width } \\
(\mathrm{cm})\end{array}$ & $\begin{array}{c}\text { Fruit } \\
\text { weight } \\
\text { (g) }\end{array}$ & $\begin{array}{c}\text { Fruit } \\
\text { volume } \\
\left(\mathrm{cm}^{3}\right)\end{array}$ \\
\hline $\mathrm{T}_{1}: \mathrm{GA}_{3}(100 \mathrm{ppm})$ & 22.60 & 77.40 & 42.23 & 11.37 & 7.28 & 135.78 & 125.22 \\
\hline $\mathrm{T}_{2}:$ Urea $(1.5 \%)$ & 19.59 & 80.41 & 38.86 & 11.33 & 7.14 & 129.52 & 120.56 \\
\hline $\mathrm{T}_{3}$ : Boron $(0.2 \%)$ & 27.79 & 72.21 & 43.99 & 11.42 & 7.35 & 144.12 & 126.11 \\
\hline $\mathrm{T}_{4}:$ Boron $(0.2 \%)+\mathrm{GA}_{3}(100 \mathrm{ppm})$ & 27.18 & 72.82 & 47.44 & 11.48 & 7.46 & 156.32 & 131.67 \\
\hline $\mathrm{T}_{5}:$ Urea $(1.5 \%)+\mathrm{GA}_{3}(100 \mathrm{ppm})$ & 31.54 & 68.46 & 55.99 & 11.61 & 7.62 & 177.14 & 136.78 \\
\hline $\mathrm{T}_{6}:$ Boron $(0.2 \%)+$ Urea $(1.5 \%)$ & 29.98 & 70.02 & 52.04 & 11.52 & 7.55 & 161.02 & 134.67 \\
\hline $\mathrm{T}_{7}:$ Boron $(0.2 \%)+$ Urea $(1.5 \%)+\mathrm{GA}_{3}(100 \mathrm{ppm})$ & 35.50 & 64.50 & 58.66 & 11.75 & 7.81 & 189.24 & 137.45 \\
\hline $\mathrm{T}_{8}:$ Water control & 16.25 & 83.75 & 35.41 & 11.22 & 7.02 & 121.65 & 119.67 \\
\hline S. Em \pm & 1.24 & 0.41 & 3.14 & 0.05 & 0.03 & 3.14 & 4.40 \\
\hline CD At $5 \%$ & 3.76 & 1.27 & 9.43 & 0.164 & 0.115 & 9.544 & NS \\
\hline
\end{tabular}

Table 1.2: Effect of foliar feeding of nutrients and gibberellic acid on quality parameters of mango.

\begin{tabular}{|c|c|c|c|c|c|c|}
\hline Treatments & $\begin{array}{c}\text { Total soluble } \\
\text { solids }(\%)\end{array}$ & $\begin{array}{l}\text { Reducing } \\
\text { sugar (\%) }\end{array}$ & $\begin{array}{c}\text { Non reducing } \\
\text { sugars }\end{array}$ & $\begin{array}{c}\text { Total sugar } \\
(\%)\end{array}$ & $\begin{array}{l}\text { Ascorbic acid } \\
\mathrm{mg} / 100 \mathrm{~g} \text { pulp }\end{array}$ & $\begin{array}{l}\text { Acidity } \\
\text { per cent }\end{array}$ \\
\hline $\mathrm{T}_{1}: \mathrm{GA}_{3}(100 \mathrm{ppm})$ & 19.01 & 2.21 & 11.78 & 13.99 & 40.74 & 0.169 \\
\hline $\mathrm{T}_{2}:$ Urea $(1.5 \%)$ & 18.56 & 2.10 & 11.44 & 13.54 & 40.10 & 0.172 \\
\hline $\mathrm{T}_{3}$ : Boron $(0.2 \%)$ & 19.38 & 2.54 & 11.91 & 14.45 & 41.12 & 0.161 \\
\hline $\mathrm{T}_{4}:$ Boron $(0.2 \%)+\mathrm{GA}_{3}(100 \mathrm{ppm})$ & 19.92 & 2.82 & 12.12 & 14.94 & 41.91 & 0.159 \\
\hline $\mathrm{T}_{5}:$ Urea $(1.5 \%)+\mathrm{GA}_{3}(100 \mathrm{ppm})$ & 21.12 & 3.43 & 12.98 & 16.41 & 42.82 & 0.148 \\
\hline $\mathrm{T}_{6}:$ Boron $(0.2 \%)+$ Urea $(1.5 \%)$ & 20.52 & 3.05 & 12.54 & 15.59 & 42.11 & 0.152 \\
\hline $\mathrm{T}_{7}:$ Boron $(0.2 \%)+$ Urea $(1.5 \%)+\mathrm{GA}_{3}(100 \mathrm{ppm})$ & 21.88 & 4.12 & 13.65 & 17.77 & 43.34 & 0.134 \\
\hline $\mathrm{T}_{8}:$ Water control & 17.95 & 2.01 & 10.92 & 12.93 & 39.55 & 0.177 \\
\hline S. Em \pm & 0.115 & 0.033 & 0.050 & 0.048 & 0.191 & 0.004 \\
\hline CD at $5 \%$ & 0.351 & 0.102 & 0.153 & 0.146 & 0.581 & 0.012 \\
\hline
\end{tabular}


similarly. While increased in sugar per cent may be due to involve in the translocation of more sugar to the fruits. It has been reported that there is a greater conversion of starch into sugar (source to sink) in the presence of these nutrients. The results are in closed conformity with the finding of Vashistha et al. (2010) in Banarasi Karaka, they obtained maximum total soluble solid with the foliar application of urea @ 1\%+ZnSO @ 0.4\%+Borax @ 0.4\% whereas minimum with water spray (control) in mango fruit (Mangifera indica L.) cv. Amrapali and also Bakshi et al. (2013) obtained maximum TSS ${ }^{\circ}$ Brix in strawberry $\mathrm{cv}$. Chandler with the foliar application of $0.6 \% \mathrm{ZnSO}_{4}$. Rajak et al. (2010) reported maximum response in mango cv. Amrapali in ascorbic acid content (mg/100 g pulp) with a foliar spray of $\mathrm{ZnSO}_{4} @ 0.6 \%$ and Borax @ 0.8\% and minimum in control and Bhowmick et al. (2012) also reported maximum total sugars and nonreducing sugar with an application of $\mathrm{ZnSO}_{4} @ 1.0 \%$ in mango cv. Amrapali.

\section{CONCLUSION}

The study on the foliar spray of nutrients and plant growth regulators on mango revealed significantly better response on Physico-chemical characters of mango. In this study, all the treatments gave superior results while the treatment having Boron (0.2\%) + Urea (1.5\%) + GA3 (100 ppm) was considered better for improving the growth, yield and chemical parameters of mango which may add the better economics to mango growers.

Conflicts of Interest: None.

\section{REFERENCES}

A.O.A.C. (1975). Official Method of Analysis. Association of Official Analytical Chemists (12 ${ }^{\text {th }}$ edn.), Washington. D.C.

Anonymous (2017). Area and Production of Horticultural Crops in Gujarat. Dept. of Horticulture, Gujarat state.

Babu, K.D., Dubey, A.K. and Yadav, D.S. (2007). Effect of micronutrients on enhancing the productivity and quality of Kinnow mandarin. Indian J. Hort. 64(3): 353-356.

Bakshi, P., Jasrotia, A., Wali, V.K., Sharma, A. and Bakshi, M. (2013). Influence of pre-harvest application of calcium and micronutrients on growth, yield, quality and shelf-life of strawberry cv. Chandler. Indian Journal of Agricultural Sciences. 83(8): 831-835.

Bhowmick, N. Banic, B.C., Hasan, M.A. and Ghosh, B. (2012). The response of pre-harvest foliar application of zinc and boron on mango cv. Amrapali under new Alluvial zone of West Bengal. Indian J. Hort. 69(3): 428-431.

Hamdy, Ibrahim, I.M., Ahmed, Mohamed, Y. and Ahmed, F.F. (2007). Relation of fruiting in Hindy Bisinara mangoes to foliar nutrition with $\mathrm{Mg}, \mathrm{B}$ and $\mathrm{Zn}$ and some Antioxidants. African Crop Science Conference Proceedings. 8: 411-415.

Hasani, M., Zamani, Z., Savaghebi, G. and Fatahi, R. (2012). Effects of zinc and manganese as a foliar spray on pomegranate yield, fruit quality and leaf minerals. Soil Sci. and PI. Nutri. 12(3): 471-480.
Jat, G. and Kacha, H.L. (2014). The response of guava to foliar application of urea and zinc on fruit set, yield and quality. Agri. Search. 1(2): 86-91.

Kumar, S., Yadav, A.L., Vishwakarma, G. and Yadav, D.K. (2014). Effect of foliar feeding of nutrients and plant growth regulators on Physico-chemical attributes of phalsa (Grewia subinaequalis D.C.). Res. Environ. Life Sci. 7(4) 317- 318.

Martinez-Romero, D., Valero, D., Serrano, M., Burlo, F., Carbonell, A., Burgos, L. and Riquelme, F. (2000). Exogenous polyamines and gibberellic acid effects on peach (Prunus persica L.) storability improvement. J. Food Sci. 65: 288294.

Moazzam, A., Tahir, F.M., Shahzad, J. and Mahmood, N. (2011). Effect of foliar application of micronutrients on the quality of mango (Mangifera indica L.) cv. Dashehari fruit. Mycopath. 9(1): 25-28.

Nehete, D.S., Padhiar, B.V., Shah, N.I., Bhalerao, P.P., Kolambe, B.N. and Bhalerao, R.R. (2011). Influence of micronutrient spray on flowering, yield, quality and nutrient content in the leaf of mango cv. Kesar. Asian J. Horti. 6(1): 63-67.

Pandey, S.K. and Jain, P.K. (2014). Effect of micronutrients, growth regulators and bio-fertilizers on biochemical composition of mango cv. Langra. Inter. J. Sci. Res. 3(12): 146-147.

Purseglove, J.W. (1972). Mangoes west of India. Acta. Hort. 24: 170-174.

Ram, S. (1983). Hormonal control of fruit growth and fruit drop in mango cv. Dashehari. Acta Hort. 134: 169-78.

Rajak, U., Rani, R., Kumar, R., Mandal, B.K. and Prasad, K.K. (2010). Effect of foliar application of urea, borax and zinc on flowering, fruiting and fruit quality of Amrapali mango. Environment and Ecology. 28(3): 1668-1671.

Ranganna, S. (1979). Manual of analysis of fruit and vegetable products. Tata-McGraw Hill Publishing Company Ltd., New Delhi.

Singh, V.K., Bhriguvanshi, S.R., Yadava, L.P. and Chatterjee, C. (2009). Effect of micronutrients on growth and yield of mango cv. Dashehari. Asian J. Hort. 4(1): 112-115.

Tripathi, V.K. and Shukla, P.K. (2006). Effect of plant bioregulator on growth, yield and quality of strawberry $\mathrm{cv}$. Chandlar. J. Asian Hort. 2(4): 260.

Vashistha, K., Yadav, A.L., Singh, H.K. and Yadav, D.K. (2010). Effect of foliar spray of nutrients on fruit drop, yield and quality attributes of mango fruit (Mangifera indica L.) cv. Amrapali. Plant Archives 10(1): 359-360.

Vejendla, V., Maity, P.K. and Banik, B.C. (2008). Effect of chemicals and growth regulators on fruit retention, yield and quality of mango cv. Amrapali. Journal of Crop and Weed. 4(2): 45-46.

Vishwakarma, G., Yadav, A.L., Singh H.K. and Singh, J. (2013). Effect of foliar feeding of Calcium and Boron on yield and quality of aonla (Emblica officinalis Gaertn.) cv. NA6. Plant Archives. 13(2): 1135-1138. 